DOI https://doi.org/10.18551/rjoas.2018-03.16

\title{
ANALYSIS OF DECISION FACTORS TO PURCHASE ORGANIC FERTILIZER BY WHITE PEPPER FARMERS
}

\author{
Kusumah Echo Perdana, Christianingrum Mrs \\ Faculty of Economics, University of Bangka Belitung, Indonesia \\ E-mail: echo perdana@ubb.ac.id
}

\begin{abstract}
This study aims to determine the effect of farmers' perceptions of quality and attitudes toward purchasing decisions. Population in this study is white pepper farmers in Bangka Belitung Province, Indonesia. The method of determining the samples is performed by the quota method, based on sampling criteria performed then the number of samples selected as many as 97 farmers. The results show that the perception of quality has a positive and significant effect on purchasing decisions; the farmer's attitude has a positive and significant effect on purchasing decisions and simultaneously has a significant effect. The decision to purchase organic fertilizer by respondents is not qualified concerning productivity.
\end{abstract}

\section{KEY WORDS}

Farmers, quality perceptions, attitudes perceptions, purchasing decisions.

The era of globalization that is happening to this day. Age makes the development of agricultural technology that is increasingly beneficial to the environment, to make people more efficiently run the activities in his life every day and care about the surrounding environment (Klerkx, L., Aarts, N., \& Leeuwis, C., 2010). One type of technology that is very influential for farmers today is organic fertilizer (Noltze, M., Schwarze, S., \& Qaim, M., 2013). Organic Fertilizer is the most potent fertilizer from the material of the remains of living creatures either in the form of crops or livestock waste, such as straw, straw, rice husk, coffee skin, cattle dung, snail shells or shells and others which are then processed through fermentation process or decomposition (Polprasert, C., 2017).

The world of agriculture is currently incessantly implementing go green program in which all food products are organic (De Schutter, O., \& Vanloqueren, G., 2011). The use of organic fertilizer is not new because the use of fertilizer is part of agricultural history (Dahlberg, K. (Ed.)., 2012). The use of fertilizer is estimated to have started since the beginning of humans knows farming, which is about several thousand years ago (Monastersky, R., 2015). The primitive form of fertilizer use in improving soil fertility starts from the old human culture in the Nile, Euphrates, Indus, China and Latin America rivers (Monastersky, R. (2015). In Indonesia, organic fertilizer has long been known to farmers, the population of Indonesia has known organic fertilizer long before the implementation of the green revolution in Indonesia (Jain, H. K., 2010). After the green revolution, most farmers prefer to use artificial fertilizers because it is practical to use and more efficient, easy to obtain (Jain, H. K., 2010).

Most farmers are heavily dependent on artificial fertilizers (chemical), which can negatively impact the development of agricultural production and decrease soil fertility since the use of chemical fertilizers, in the long run, will actually "kill" the soil (Sudtasan, T., \& Suriya, K., 2012). In this case, farmers are faced with two options, namely using organic fertilizer or using an inorganic fertilizer that is already inherent in the farmers. The use of organic fertilizer by farmers can be influenced by the perception of the fertilizer (Ajewole, O. C., 2010). If the first perception obtained by farmers, it will lead to a decision to buy organic fertilizer.

Perception is a learning experience about the object of events or relationships obtained by concluding information and interpreting messages (Broadbent, D. E., 2013). Many factors can influence a person's decision to make a purchase. According to Kotler, P., \& Armstrong, G. (2013), a person's purchasing decisions can be influenced by the 
motivation of perception and attitude. Kotler \& Armstrong's earlier statements are in line with Tan, B., \& Lau, T. C. (2011) which states that a person's decision to make a purchase is influenced by perception and attitude.

Farmers as consumers in making purchasing decisions will consider several factors, including the perception of quality (De Cannière, M. H., De Pelsmacker, P., \& Geuens, M., 2010). Perception of quality is the consumer's perception of the overall quality or superiority of a product or service related to what is expected by the customer (Kenyon, G.N., \& Sen, K. C., 2016). Consumer perceptions of a product can come from information received or from past consumer experience (Kenyon, G. N., \& Sen, K. C., 2016). Perception, each consumer on the quality of a product, will vary. Perceptions that appear can be both positive and negative. Attitude is an evaluation, a person's feelings, and a favourable or unfavourable and enduring tendency towards someone for a particular object or idea (Kotler, P., 2012). Consumers will believe in the information it receives and chooses a particular brand to buy, and it is related to the attitude developed (Lin, L. Y., 2010).

Consumer beliefs and preferences of a brand is a consumer attitude (Buil, I., Martínez, E., \& De Chernatony, L., 2013). In many ways, attitudes toward a particular brand often affect whether consumers will buy or not. A positive attitude toward a particular brand will allow consumers to purchase the brand; otherwise negative attitudes will deter consumers genuinely make a purchase (Oliver, R. L., 2014). Based on the phenomenon and some previous research above, the researchers are interested to know the influence of the perception of quality and attitude of white pepper farmers to the decision to purchase organic fertilizer in Bangka Belitung Province, Indonesia.

\section{METHODS OF RESEARCH}

This study uses a quantitative approach. According to Babbie, E. R. (2010) quantitative methods emphasize objective measurements and the statistical, mathematical, or numerical analysis of data collected through polls, questionnaires, and surveys, or by manipulating preexisting statistical data using computational techniques. Quantitative research focuses on gathering numerical data and generalizing it across groups of people or explaining a particular phenomenon (Mujis, D., 2010). Data collection through research instruments in the form of questionnaires, data analysis is statistical or quantitative aims to test the hypothesis. The hypotheses proposed by researchers are:

$\mathrm{H} 1$ : The existence of quality perception has the positive and significant influence on white pepper farmer decision in purchasing organic fertilizer.

$\mathrm{H} 2$ : The existence of attitude perception has the positive and significant influence on white pepper farmer decision in purchasing organic fertilizer.

H3: The existence of quality and attitude perception has the positive and significant influence on white pepper farmer decision in purchasing organic fertilizer

The place of this research was conducted in Bangka Belitung Province, Indonesia. Bangka Belitung Province is famous as one of the world's white pepper commodities producer named Muntok White Pepper (International Pepper Community). Samples in this research are some white pepper farmer representing 4 Regency in Bangka Belitung Province (see table 1).

Table 1 - Distribution of samples

\begin{tabular}{|c|c|c|c|}
\hline No & Regency & Samples & Productivity Characteristics \\
\hline 1 & South Bangka & 37 & High \\
\hline 2 & West Bangka & 20 & Medium \\
\hline 3 & Bangka & 20 & Medium \\
\hline 4 & Central Bangka & 20 & Medium \\
\hline & Total & 97 & - \\
\hline
\end{tabular}

Source: Data processed by researchers, 2017.

The number of samples to be used in this study is determined by using quota sampling technique. Quota sampling method is a non-probability sampling, and it can be defined as a 
sampling method of gathering representative data from a group (Saunders, M., Lewis, P. \& Thornhill, A., 2012). Application of quota sampling ensures that sample group represents particular characteristics of the population chosen by the researcher (Saunders, M., Lewis, P. \& Thornhill, A., 2012).

In this study, the researcher uses the Likert scale as a variable measuring instrument. The Likert scale according to Sugiyono (2016) is used to measure opinions, attitudes, and perceptions of a person or a group of people about a social phenomenon. The method of calculation used on the Likert scale itself is to ask a respondent some questions, and then the respondent is asked to provide an answer. The answer to each question item has gradation strongly agree to disagree strongly then it will be given a weight value from 1 to 5 (Sugiyono, 2016). The descriptive statistical analysis used in this study is a statistic used in data analysis by describing the data that has been collected as it is without intending to make generalized conclusions. The formula to calculate the magnitude of the questionnaire results interval is as follows:

$$
\text { Range }=\frac{\text { Highest score }- \text { Lowest score }}{\text { Total of classification }}
$$

Table 2 - Interval scale on Likert

\begin{tabular}{ccc}
\hline No. & Interval Scale & Information \\
\hline 1. & $1,00-1,80$ & Very low \\
2. & $1,81-2,60$ & low \\
3. & $2,61-3,40$ & Medium \\
4. & $3,41-4,20$ & High \\
5. & $4,21-5,00$ & Very high \\
\hline
\end{tabular}

Source: Adapted from Sugiyono (2016).

Test of research instrument using validity and reliability test. An instrument is said to be valid if it can measure what is desired or reveal the data of the variables studied appropriately (Ferdinand, 2014). The testing technique for validity test is using Bivariate Pearson correlation. Bivariate Pearson analysis is done by correlating each item score with a total score (Ghozali, 2016). Test validity is done by comparing r-count with r-table with significant $5 \%$, if $r$-count $>$ r-table then declared valid (Ghozali, 2016). Conversely, if $r$-count $<r$-table then the data declared invalid. Meanwhile, reliability test is a tool to test the level of trust (reliability) questionnaire instrument which is an indicator of the variable to know the consistency of the measuring tool and consistent if the measurement is repeatedly done from time to time (Sugiyono, 2016). The method used in this research is Cronbach's Alpha method. Reliability test is done by comparing $r$-count with $r$-table with significant $5 \%$, if $r$ count $>$ r-table then declared reliable (Ghozali, 2016). Conversely, if $r$-count $<$ r-table then the data declared not reliable.

In addition to the above instrument test, there are also inferential statistical tests of logistic regression analysis. Before multiple regression analysis is applied, it is necessary to ensure that data has BLUE (Best Linear Unbiased Estimator) criteria (Gujarati, 2004). To apply BLUE criterion, the researcher tested the data with normality test, multicollinearity test and heteroskedasticity test. The normality test is intended to show that samples are taken from normally distributed populations (Sugiyono, 2016). The technique used to test normality in this study through Kolgomorov-Smirnov test. Kolgomorov-Smirnov test criteria for normally distributed data are p-value (Sig.) > 0.05 (Ghozali, 2016). Then, multicollinearity test is a regression model test tool used to find the correlation between independent variables. A good regression model should not occur correlation between independent variables (Sugiyono, 2016). The multicollinearity test can be done by looking at the VIF (Variance Inflation Factor) value and its tolerance value (Ghozali, 2016). The criterion is that if the VIF value is between $1-10$ and the tolerance value of $\geq 0.1$, then there can be no multicollinearity problem (Ghozali, 2016). While heteroskedasticity test is one of the regression model test tools to determine whether there is inequality of variance from residual one observation to 
another observation (Sugiyono, 2016). If the variance value of the residual one observation to another observation remains, then it is said homoskedasticity and if different it is said heteroscedasticity (Ghozali, 2016). A regression model is said to be good if the model is homoscedasticity or there is no heteroskedasticity problem. One method to detect the presence of symptoms of heteroskedasticity is by park test. The criterion is if the value of significance on the variable $>0.05$, then it can be said there is no problem heteroskedasticity (Ghozali, 2016).

After BLUE is applied, next is to analyze the data with multiple linear regression analysis. The analysis is used to measure how far the influence of quality perception and attitude perception to the decision of purchasing organic fertilizer. Multiple linear regression analysis was performed using SPSS 25.0 application. SPSS application proved to facilitate researchers in the processing of quantitative data (Kusumah, 2018). In general, the form of regression line equation can be formulated as follows:

$$
Y=a+b_{1} X_{1}+b_{2} X_{2}
$$

Where:

Y: Purchase Decision (dependent);

a: Constants;

$\mathrm{X}_{1}$ : Quality perception (independent);

$\mathrm{X}_{2}$ : Attitude perception (independent);

$b_{1}-b_{2}$ : Regression coefficients for each independent variable.

Hypothesis testing has been described previously using t-test and f-test. A t-test or partial test shows how much influence of independent variable to dependent variable individually/ partially. Ho: $\mathrm{H}_{1}-\mathrm{H}_{2}=0$, Show there is no influence between independent variable to dependent variable. $\mathrm{Ha}: \mathrm{H}_{1}-\mathrm{H}_{2} \neq 0$, Show there is influence between independent variable to dependent variable. The decision criterion is if the significance value (Sig.) $<0.05$, then $\mathrm{Ho}$ is rejected and $\mathrm{Ha}$ accepted. Meanwhile, the f-test or simultaneous test is used to determine whether the independent variable influences the dependent variable simultaneously or together. The test criterion is similar to the t-test. After testing the hypothesis, the final test is the coefficient of determination test. This test uses an adjusted $\mathrm{R}^{2}$ value. This test is used to find out how far the independent variable can explain the dependent variable. The value lies between 0 and 1 . If the value is close to 0 , then the ability of the dependent variable to explain the independent variable is insufficient. If the value is close to 1 means, the dependent variable has the ability to explain the independent variable.

\section{RESULTS OF STUDY}

Characteristics of respondents in this study are the primary data obtained from the distribution of questionnaires to respondents, i.e. white pepper farmers. Data from 97 respondents in this study include sex, age, and occupation. Here is a description of the characteristics of respondents in this study based on gender and age:

Table 3 - Characteristics of Respondents by Gender

\begin{tabular}{cccc}
\hline No. & Gender & Frequency & Percentage (\%) \\
\hline 1 & Male & 83 & 85.6 \\
2 & Female & 14 & 14.4 \\
\hline & Total & 97 & 100 \\
\hline
\end{tabular}

Source: Data processed by researchers, 2017.

Based on these data it can be concluded that white pepper farmers are dominated by male gender (85.6\%). 
Table 4 - Characteristics of Respondents by Age

\begin{tabular}{cccc}
\hline No. & Age & Frequency & Percentage $(\%)$ \\
\hline 1 & $<! 8$ year & 4 & 4.1 \\
2 & $18-25$ year & 5 & 5.2 \\
3 & $26-32$ year & 18 & 18.6 \\
4 & $>32$ year & 70 & 72.2 \\
\hline & Total & 97 & 100 \\
\hline
\end{tabular}

Source: Data processed by researchers, 2017.

Based on these data it can be concluded that white pepper farmers are dominated by more than 32 years old farmers $(72.2 \%)$. Recapitulation of respondents' answers to perceptual variables of quality through statistical description analysis is shown in the table below:

Table 5 - Respondents' answers

\begin{tabular}{|c|c|c|c|c|c|c|c|c|c|}
\hline \multirow[b]{2}{*}{$\begin{array}{l}\text { No. } \\
\text { item }\end{array}$} & \multicolumn{5}{|c|}{ Answer Frequency } & \multirow[b]{2}{*}{$\mathrm{N}$} & \multirow[b]{2}{*}{$\begin{array}{l}\text { Total } \\
\text { Score }\end{array}$} & \multirow[b]{2}{*}{$\begin{array}{l}\text { Mean } \\
\text { Score }\end{array}$} & \multirow[b]{2}{*}{ Conclusion } \\
\hline & $\begin{array}{l}\text { Strongly } \\
\text { Agree (5) }\end{array}$ & $\begin{array}{l}\text { Agree } \\
\text { (4) }\end{array}$ & $\begin{array}{c}\text { Neutral } \\
(3)\end{array}$ & $\begin{array}{c}\text { Not } \\
\text { Agree } \\
(2)\end{array}$ & $\begin{array}{c}\text { Strongly Not } \\
\text { Agree (1) }\end{array}$ & & & & \\
\hline 1 & 3 & 6 & 37 & 33 & 18 & 97 & 234 & 2.41 & Low \\
\hline 2 & 1 & 9 & 27 & 44 & 16 & 97 & 226 & 2.33 & Low \\
\hline \multirow[t]{2}{*}{3} & 2 & 6 & 22 & 42 & 25 & 97 & 209 & 2.15 & Low \\
\hline & \multicolumn{5}{|c|}{ Average Mean Quality Perception } & & & 2.30 & Low \\
\hline
\end{tabular}

Source: Data processed by researchers, 2017.

Based on table 5 above the mean or average score of 2.30 from $5.00(46 \%)$. So the results can be concluded that the respondents or white pepper farmers in Bangka Belitung assume that the quality of organic fertilizer is low when compared with chemical fertilizers. Recapitulation of respondents' answers to perceptual variables of attitude through mathematical description analysis is shown in the table below.

Table 6 - Respondents' answers

\begin{tabular}{|c|c|c|c|c|c|c|c|c|c|}
\hline \multirow[b]{2}{*}{$\begin{array}{l}\text { No. } \\
\text { item }\end{array}$} & \multicolumn{5}{|c|}{ Answer Frequency } & \multirow[b]{2}{*}{$\mathrm{N}$} & \multirow[b]{2}{*}{$\begin{array}{l}\text { Total } \\
\text { Score }\end{array}$} & \multirow{2}{*}{$\begin{array}{l}\text { Mean } \\
\text { Score }\end{array}$} & \multirow[b]{2}{*}{ Conclusion } \\
\hline & $\begin{array}{c}\text { Strongly } \\
\text { Agree (5) }\end{array}$ & $\begin{array}{l}\text { Agree } \\
\text { (4) }\end{array}$ & $\begin{array}{c}\text { Neutral } \\
(3)\end{array}$ & $\begin{array}{c}\text { Not Agree } \\
(2)\end{array}$ & $\begin{array}{l}\text { Strongly Not } \\
\text { Agree (1) }\end{array}$ & & & & \\
\hline 1 & 0 & 4 & 20 & 48 & 25 & 97 & 197 & 2.03 & Low \\
\hline 2 & 0 & 1 & 19 & 47 & 30 & 97 & 185 & 1.91 & Low \\
\hline \multirow[t]{2}{*}{3} & 0 & 0 & 24 & 44 & 29 & 97 & 189 & 1.95 & Low \\
\hline & \multicolumn{5}{|c|}{ Average Mean Attitude Perception } & & & 1.96 & Low \\
\hline
\end{tabular}

Source: Data processed by researchers, 2017.

Based on table 6 above the mean or mean value of 1.96 from 5.00 (39.2\%). So the results can be concluded that the respondents or white pepper farmers in Bangka Belitung have a low attitude toward organic fertilizer when compared with chemical fertilizers. Recapitulation of respondents' answers to perceptual variables of purchasing decision through statistical description analysis is shown in the table below.

Table 7 - Respondents' answers

\begin{tabular}{|c|c|c|c|c|c|c|c|c|c|}
\hline \multirow[b]{2}{*}{$\begin{array}{l}\text { No. } \\
\text { item }\end{array}$} & \multicolumn{5}{|c|}{ Answer Frequency } & \multirow[b]{2}{*}{$\mathrm{N}$} & \multirow{2}{*}{$\begin{array}{l}\text { Total } \\
\text { Score }\end{array}$} & \multirow{2}{*}{$\begin{array}{l}\text { Mean } \\
\text { Score }\end{array}$} & \multirow[b]{2}{*}{ Conclusion } \\
\hline & $\begin{array}{l}\text { Strongly } \\
\text { Agree (5) }\end{array}$ & $\begin{array}{c}\text { Agree } \\
\text { (4) }\end{array}$ & $\begin{array}{l}\text { Neutral } \\
\text { (3) }\end{array}$ & $\begin{array}{l}\text { Not Agree } \\
\text { (2) }\end{array}$ & $\begin{array}{l}\text { Strongly Not } \\
\text { Agree (1) }\end{array}$ & & & & \\
\hline 1 & 0 & 3 & 29 & 38 & 27 & 97 & 202 & 2.08 & Low \\
\hline 2 & 1 & 12 & 24 & 35 & 25 & 97 & 215 & 2.22 & Low \\
\hline 3 & 0 & 0 & 14 & 53 & 30 & 97 & 178 & 1.83 & Low \\
\hline \multirow[t]{2}{*}{4} & 1 & 4 & 32 & 39 & 21 & 97 & 216 & 2.23 & Low \\
\hline & \multicolumn{5}{|c|}{ Average Mean Quality Perception } & & & 2.09 & Low \\
\hline
\end{tabular}

Source: Data processed by researchers, 2017. 
Based on table 7 above the mean value of 2.09 from 5.00 (41.8\%). So the results can be concluded that the respondents or white pepper farmers in Bangka Belitung have a low purchasing decision toward organic fertilizers when compared with chemical fertilizers.

In testing the instrument has been tested the validity and reliability. The test uses $r$ table of 0.1996 (two-tailed, $\mathrm{df}=\mathrm{n}-2$ ) as a comparison with r-count. The result of validity and reliability test in this research can be seen in the following table:

Table 8 - Validity and Reliability Tests

\begin{tabular}{|c|c|c|c|c|c|c|}
\hline Variable & Item & $r_{\text {count }}$ (Validity) & $r_{\text {count }}($ Reliability) & $r_{\text {table }}$ & \multicolumn{2}{|c|}{ Information } \\
\hline \multirow{3}{*}{$\begin{array}{l}\text { Attitude Perception } \\
\text { (A) }\end{array}$} & A1 & .848 & \multirow{3}{*}{.772} & \multirow{3}{*}{.1996} & Valid & \multirow{3}{*}{ Reliable } \\
\hline & A2 & .861 & & & Valid & \\
\hline & A3 & .778 & & & Valid & \\
\hline \multirow{3}{*}{$\begin{array}{l}\text { Quality Perception } \\
\text { (Q) }\end{array}$} & Q1 & .832 & \multirow{3}{*}{.656} & \multirow{3}{*}{1996} & Valid & \multirow{3}{*}{ Reliable } \\
\hline & Q2 & .783 & & & Valid & \\
\hline & Q3 & .696 & & & Valid & \\
\hline \multirow{4}{*}{$\begin{array}{l}\text { Purchasing Decision } \\
\text { (PD) }\end{array}$} & PD1 & .817 & \multirow{4}{*}{.735} & \multirow{4}{*}{.1996} & Valid & \multirow{4}{*}{ Reliable } \\
\hline & PD2 & .817 & & & Valid & \\
\hline & PD3 & .694 & & & Valid & \\
\hline & PD4 & 669 & & & Valid & \\
\hline
\end{tabular}

Source: Data processed by researchers, 2017.

From table 8 above shows that $r$-count $>$ r-table so it can be concluded that all items and instrument variables declared valid and reliable. After tested the validity and reliability of the instrument, the next step is to test data with BLUE terms. Normality test can be seen in the figure below.
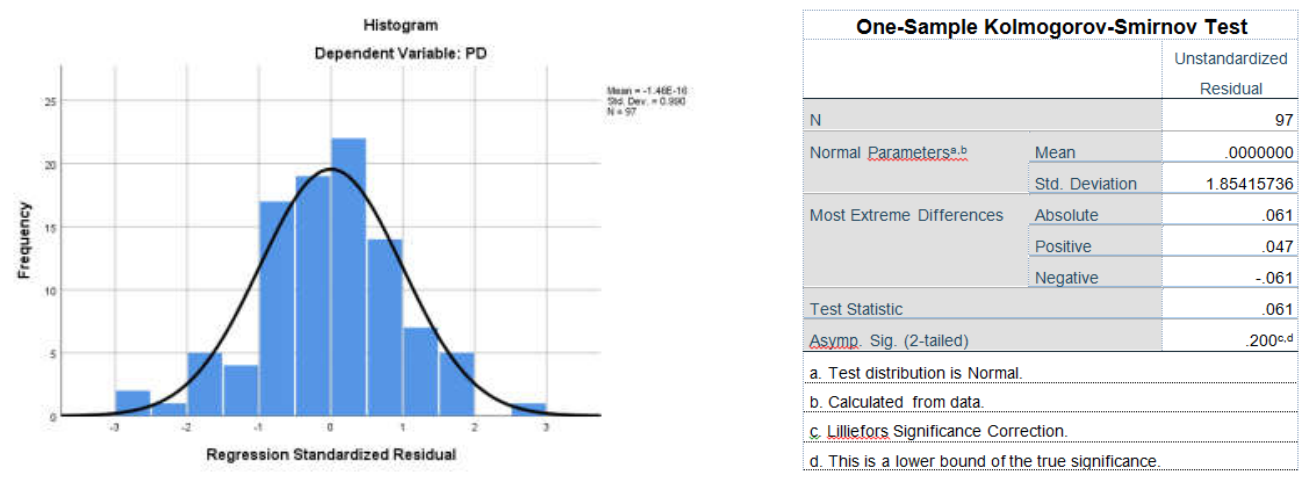

Source: Data processed by researchers, 2017.

Figure 1 - Normality test

From figure 1 above can be seen that the location of histogram normality in the middle follow the parabolic line, it can be said data in this study have a normal distribution. While in figure 1 above Kolgomorov-Smirnov test shows the value of Asymp. Sig. (2-tailed) $0.200>$ 0.05 so it can be concluded that the data is normally distributed. The next BLUE test is a multicollinearity test. Multicollinearity test results can be seen below:

Table 9 - Multicollinearity test

\begin{tabular}{cccc}
\hline \multirow{2}{*}{ Variables } & \multicolumn{2}{c}{ Collinearity Statistics } & \multirow{2}{*}{ Information } \\
\cline { 2 - 3 } & Tolerance & VIF & \\
\hline Attitude Perception & .771 & 1.297 & There is no multicollinearity problem \\
\hline Quality Perception & .771 & 1.297 & There is no multicollinearity problem \\
\hline
\end{tabular}

Source: Data processed by researchers, 2017.

Based on the results in table 9, multicollinearity test above shows that the tolerance value for each independent variable is between $0-1$ and the VIF value for each independent 
variable is between 1-10 it can be concluded that there is no multicollinearity problem or there is no correlation between each independent variable. The next test is a heteroscedasticity test. Here are the results of heteroscedasticity test using scatterplot and Glejser Test.

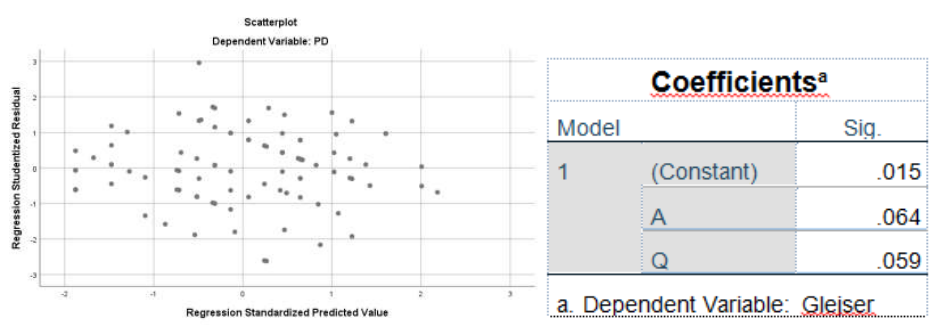

Source: Data processed by researchers, 2017.

Figure 2 - Heteroscedasticity test

Based on figure 2 above, see the dots (samples) spread randomly above and below the number 0 on the $y$-axis, and did not form a specific pattern so it can be concluded that the regression model in this study did not experience heteroskedasticity problem. While in figure 2 above heteroskedasticity test with Glejser test seen Significance value all independent variables $>0.05$, it can be concluded that the regression model does not experience heteroskedasticity problems. After BLUE is fulfilled, then the next analysis is multiple linear regression analysis, where the analysis has several tests such as t-test, f-test, beta value and coefficient of determination. The results of multiple regression analysis can be seen in the following table:

Table 10 - Beta values

\begin{tabular}{ccccc}
\hline \multirow{2}{*}{ Model } & \multicolumn{2}{c}{ Unstandardized Coefficients } & Standardized Coefficients \\
\cline { 3 - 5 } & B & Std. Error & Beta \\
\hline \multirow{2}{*}{1} & (Constant) & 2.064 & .726 & \\
& Attitude $\left(\mathrm{X}_{1}\right)$ & .665 & .115 & .491 \\
& Quality $\left(\mathrm{X}_{2}\right)$ & .353 & .100 & .300 \\
\hline
\end{tabular}

a. Dependent Variable: Purchasing Decision ( $Y$ )

Source: Data processed by researchers, 2017.

Based on data from table IV.35 above, regression equation can be formed as follows:

$$
Y=2.064+0.491 X_{1}+0.300 X_{2}
$$

The equation shows that:

- The value of constant 2,064 obtained from the calculation shows that if the attitude perception variable and perceptual quality variable equal to zero, then the purchase decision is 2.064 .

- The coefficient of beta variable attitude perception variable has a positive value of 0.491 shows the relationship between attitude perception with purchasing decision which means every increase of 1 unit in attitude perception variable will cause an increase in purchasing decision variable of 0.491 and vice versa.

- The value of the beta coefficient of the quality perception variable has a positive value of 0.300 shows the relationship between the perception of quality with the purchase decision which means an increase of 1 unit in the quality perception variable will cause an increase in the purchase decision variable of 0.300 and vice versa.

Based on the results in table 11, the calculation of the sig value for $X_{1}$ is 0.000 smaller than the level of significance 0.05 . Thus it can be concluded that the attitude perception variable significantly influences the purchase decision variable. The sig value for $X_{2}$ is 0.001 
smaller than the level of significance 0.05 . Thus it can be concluded that the quality perception variable significantly influences the purchase decision variable.

Table 11 - t-test

\begin{tabular}{cccc}
\hline & Model & $\mathrm{t}$ & Sig. \\
\hline \multirow{2}{*}{1} & (Constant) & 2.841 & .006 \\
& Attitude & 5.759 & .000 \\
& Quality & 3.514 & .001 \\
\hline
\end{tabular}

a. Dependent Variable: Purchasing Decision

Source: Data processed by researchers, 2017.

Table 12 - F-test

\begin{tabular}{ccccccc}
\hline & Model & Sum of Squares & df & Mean Squares & $\mathrm{F}$ & Sig. \\
\hline 1 & Regression & 295.467 & 2 & 147.733 & 42.077 & .000 \\
& Residual & 330.038 & 94 & 3.511 & & \\
& Total & 625.505 & 96 & & & \\
\hline
\end{tabular}

a. Dependent Variable: PD

b. Predictors: (Constant), Q, A

Source: Data processed by researchers, 2017.

Based on the results in table 12, it can be seen that the significance value of 0.000 is smaller than 0.05 , it can be concluded that perceptual attitude variables and variables of quality perception simultaneously or together have a significant effect on purchasing decisions variable.

The coefficient of determination results can be seen in the following table:

Table 13 - Coefficient of determination test

\begin{tabular}{ccccc}
\hline Model & $\mathrm{R}$ & $\mathrm{R}$ Square & Adjusted R Square & Std. The error of the Estimate \\
\hline 1 & .687 & .472 & .461 & 1.874 \\
\hline
\end{tabular}

a. Predictors: (Constant), Q, A

Source: Data processed by researchers, 2017.

Based on the results in table 13, it can be seen that the value of determination coefficient (Adjusted R Square) obtained is 0.461 or $46.1 \%$. It means that the purchase decision variable can be explained by perceptual attitude variables and quality perception variables of $46.1 \%$, while the remaining $53.9 \%$ of purchasing decisions can be explained by other variables outside the variables studied.

\section{CONCLUSION AND SUGGESTIONS}

Based on the above data calculations, it can be concluded that all hypotheses mentioned above can be received positively and significantly. Based on observations, interviews, and questionnaires conducted by researchers on white pepper farmers in Bangka Belitung Province (respondents), dominant respondents choose not to buy organic fertilizer because organic fertilizer after it was tried could not increase the productivity of white pepper compared with chemical fertilizer. Organic fertilizers are only applied when the initial planting, and it was felt by the respondents did not significantly affect the productivity of white pepper. While the perception of quality of organic fertilizer, respondents feels that the quality of organic fertilizer is not as good as the quality of chemical fertilizers. The quality of organic fertilizer perceived by respondents is only suitable for farmers who come from Java. Respondents felt that if they applied organic fertilizer as the primary fertilizer, it would have an impact on their lack of farm produce. Most respondents are not concerned with 
agricultural cultivation that prioritizes organic farming systems. Respondents are only concerned with the results of white pepper as much as possible regardless of soil health.

As a suggestion, it is needed extension by the local government of Bangka Belitung Province that the planting of white pepper using organic fertilizer is better than chemical fertilizer for the long term. There needs to be further testing on applying the right organic fertilizer to the white pepper farmers. Testing can be done by researchers from abroad and in the country so that it can change the perception of white pepper farmers in the province of Bangka Belitung to be able to use organic fertilizers intensively and create conditions of white pepper farming harmonious with the environment.

\section{REFERENCES}

1. Ajewole, O. C. (2010). Farmers response to adoption of commercially available organic fertilizers in Oyo state, Nigeria. African Journal of Agricultural Research, 5(18), 24972503.

2. Babbie, E. R. (2010). The Practice of Social Research. 12th ed. Belmont. CA: Wadsworth Cengage.

3. Broadbent, D. E. (2013). Perception and communication. Elsevier.

4. Buil, I., Martínez, E., \& De Chernatony, L. (2013). The influence of brand equity on consumer responses. Journal of consumer marketing, 30(1), 62-74.

5. Dahlberg, K. (Ed.). (2012). Beyond the green revolution: The ecology and politics of global agricultural development. Springer Science \& Business Media.

6. De Cannière, M. H., De Pelsmacker, P., \& Geuens, M. (2010). Relationship quality and purchase intention and behavior: The moderating impact of relationship strength. Journal of Business and Psychology, 25(1), 87-98.

7. De Schutter, O., \& Vanloqueren, G. (2011). The new green revolution: how twenty-firstcentury science can feed the world. Solutions, 2(4), 33-44.

8. Ferdinand, Augusty. (2014). Metode Penelitian Manajemen. Semarang: Badan Penerbit Universitas Diponegoro.

9. Ghozali, I. (2016). Aplikasi Analisis Multivariate Dengan Program IBM SPSS 23. Semarang: Badan Penerbit Universitas Diponegoro.

10. Gujarati, N. D. (2004). Basic Econometrics. Fourth edition. McGraw-Hill

11. International Pepper Community. (n.d.). Retrieved September 21, 2017, from $\mathrm{http}: / / \mathrm{www}$.ipcnet.org/n/map/?path=map\&page=id

12. Jain, H. K. (2010). Green revolution: history, impact and future. The Green Revolution: History.

13. Klerkx, L., Aarts, N., \& Leeuwis, C. (2010). Adaptive management in agricultural innovation systems: The interactions between innovation networks and their environment. Agricultural systems, 103(6), 390-400.

14. Kenyon, G. N., \& Sen, K. C. (2016). Perception of Quality. Springer London Limited.

15. Kotler, P., \& Armstrong, G. (2013). Principles of Marketing.16th Global Edition. New Jersey: Pearson Prentice Hall.

16. Kotler, P. (2012). Kotler on marketing. Simon and Schuster.

17. Kusumah, E. P. (2018). Technology Acceptance Model (TAM) of Statistical Package for the Social Sciences (SPSS) Applications. Integrated Journal of Business and Economics, 2(1), 1-11.

18. Lin, L. Y. (2010). The relationship of consumer personality trait, brand personality and brand loyalty: an empirical study of toys and video games buyers. Journal of Product \& Brand Management, 19(1), 4-17.

19. Monastersky, R. (2015). The human age. Nature, 519(7542), 144.

20. Muijs, D. (2010). Doing Quantitative Research in Education with SPSS. 2nd edition. London: SAGE Publications.

21. Noltze, M., Schwarze, S., \& Qaim, M. (2013). Impacts of natural resource management technologies on agricultural yield and household income: The system of rice intensification in Timor Leste. Ecological Economics, 85, 59-68. 
22. Oliver, R. L. (2014). Satisfaction: A behavioral perspective on the consumer. Routledge.

23. Polprasert, C. (2017). Organic waste recycling: technology and management. IWA publishing.

24. Saunders, M., Lewis, P. \& Thornhill, A. (2012). Research Methods for Business Students. 6th edition. Pearson Education Limited.

25. Sudtasan, T., \& Suriya, K. (2012). Reconstruction of Farmer's Economy by Organic Agriculture: A Case of Na Huek Village in Chiang Mai. Chapter, 5, 81-92.

26. Sugiyono. (2016). Metodologi Penelitian Kuantitatif, Kualitatif, dan R\&D. Bandung: CV Alfabeta.

27. Tan, B. C., \& Lau, T. C. (2011). Green purchase behavior: Examining the influence of green environmental attitude, perceived consumer effectiveness and specific green purchase attitude. Australian Journal of Basic and Applied Sciences, 5(8), 559-567. 